\title{
Service Culture Chain: Increasing Public Satisfaction
}

\author{
Aldri Frinaldi ${ }^{1}$, Muhamad Ali Embi ${ }^{2}$, Aziza Bila ${ }^{3}$ \\ 1Department of Public Administration, Faculty of Social Science, Universitas Negeri Padang (aldri@fis.unp.ac.id), \\ ${ }^{2}$ College of Law, Government, and International Studies, Universiti Utara Malaysia, ${ }^{3}$ Department of Public \\ Administration, Faculty of Social Science, Universitas Negeri Padang
}

\begin{abstract}
Job Satisfaction is a cognitive assessment of an employee's effective evaluation of work. Employee satisfaction at work must be the main thing to be realized before satisfaction service is provide to customer. Employee who have good satisfaction at work will give a good performance, because job satisfaction is results of assessmet of employee performance toward job quality. Employee are inseparable from work culture of organization. Therefore, to improve value and image of organization, a service culture is needed to increase work satisfaction. This research uses quantitative methods with survey strategy. Determination of respondent using total sampling techniques. While data were collected using a questionnaire instrument that was valid and reliable. The collected data was processed used IBM SPSS application version 20.0. Analysis of research data was used path analysis. This study found that work culture have direct and indirect effects on job satisfaction of employee in Health Office of Pariaman City.
\end{abstract}

\section{Keywords:}

work Culture; job quality; job satisfaction

\section{Introduction}

The failure and success of an organization is influenced by human resources in the organization. The organization will be able to achieve its goals if done with effective and joint action. This explains that the attitudes / behaviors of employees are needed to support the organization for the better. Therefore, a service-based work culture is needed, so that organizations especially government organizations can provide good services, as a form of implementation of government functions.

Employee as human resources must have a work culture. The work culture must be able to give impact on performance, one of which is improve the service, so that work culture in service is very important. Service culture is one form of strategy used in order to retain employee with a customer-focused culture. This is very important because it will have an impact on the success of an organization (Edvardsson \& Enquist, 2002) 
Work culture has a very important role in extracting the best things from employees so that employees remain in the organization for a long time. Organizations must provide a comfortable and positive atmosphere for employees, so that employees concentrate on their work and do not interfere with other employees at work. In addition, the existence of a good work culture in an organization will also give an organization a move to create a conducive organization and for higher customer retention (Takada \& Westbrook, 2009).

Work culture is also an important part of bureaucratic reform that aims to improve the quality of human resources that will have an impact on improving the quality of services to the community and other stakeholders (Frinaldi, 2017). In addition, a good work culture will provide satisfaction to employees as internal customer (Frinaldi, Khaidir, \& Rahayu, 2019). Work culture was built from values that exist in religious teachings, state philosophy, habits that develop well in indigenous peoples (Frinaldi \& Embi, 2013). Appropriate and appropriate work culture is the key to achieved success of organization, because with the existence of an appropriate and appropriate work culture, have an impact on the quality of employee work. A good work culture will be directly proportional to job quality owned by its employee. The more appropriate of work culture, the better quality of work that is presented by the employee.

work culture is closely related to the quality of human resources and determine employee satisfaction in carrying out their work. To get employee satisfaction, the quality of work becomes the thing that has an influence on employee satisfaction at work, because the quality of work takes into account wages and non-wages for their work. The existence of an assessment of satisfaction by employees for their work, making them as assessors of their own satisfaction (Kponou \& Kamga, 2019)Work quality is a multidimensional concept and individuals have preferences for several elements of work quality. The origin of job quality is based on several theories. These theories help show this in the work relations, workers and employers are sensitive to non-monetary mechanisms (Sisson, Green, \& Lee, 2017). Theoretically, there is no general definition of work quality, but work quality can be understood as a dependency between values, work and its consequences (Clark, 2005).

The list of work quality that can be used as an empirical analysis includes work autonomy which consists of the task of policy and schedule control, the ability of policy, 
effort in work and work inconvenience. Work autonomy was interpreted as the level of employee independence in their work, including in making decisions, ability to solve problems, make judgments and take responsibility, all of which require knowledge and ability (Green, 2006). The measurement of work quality used in this study have seven indicators, namely sufficiency of time sufficiency (no applicable / available), job content (skill variety), autonomy (control over work), workload (work pressure and stress), recognition, employee relation management, and advancement (Cheng, Nielsen, \& Cutler, 2017).

Customer satisfaction is an emotional and cognitive response related to something that happens at a certain time (Tjiptono \& Chandra, 2007). Satisfaction or dissatisfaction is a cognitive or affective reaction that arises in response to various actions that are received at the first meeting or prolonged (rush dan oliver). Whereas in concept, satisfaction is a form of comparison of perceived quality with expected quality, whereas quality itself refers to the global evaluation of service delivery systems (Parasuraman, Zeithalm, \& Berry, 1988)

\section{Methods}

This research uses a quantitative approach with a survey strategy. Data is processed using a questionnaire that has been tested for validity and reliability. The collected data is selected from a determined population, namely employees who work under the Pariaman City Health Office. The number of samples was determined using a total sampling technique, totaling 82 respondents. Data that has been collected is processed using the IBM SPSS version 20.0 application. Data were analyzed using path analysis. This study has three variables, namely work culture as an independent variable (X1), job quality as an interveing variable $(\mathrm{X} 2)$, and employee satisfaction as a dependent variable $(\mathrm{Y})$.

\section{Results and Discussion}

This study was conducted to find formulations of work culture models that have direct and indirect effects on employee satisfaction at work. The research model can be seen in the following figure: 
Figure 1.

Research Flow

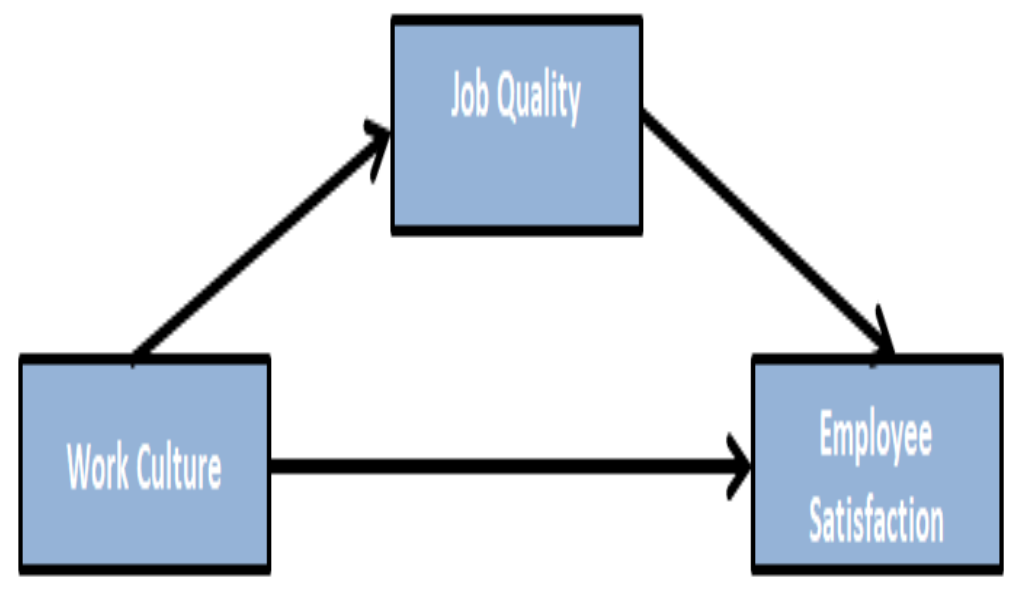

In the picture above, it can be seen that in this study there are two models. Model I is the variable X1 toward X2. the model II of this study is the variables X1 and X2 toward Y. Based on the results of data processing that has been done using the IBM SPSS application, a classic assumption test is conducted on the research variables, as below:

Figure 2.

Normality Test

Histogram

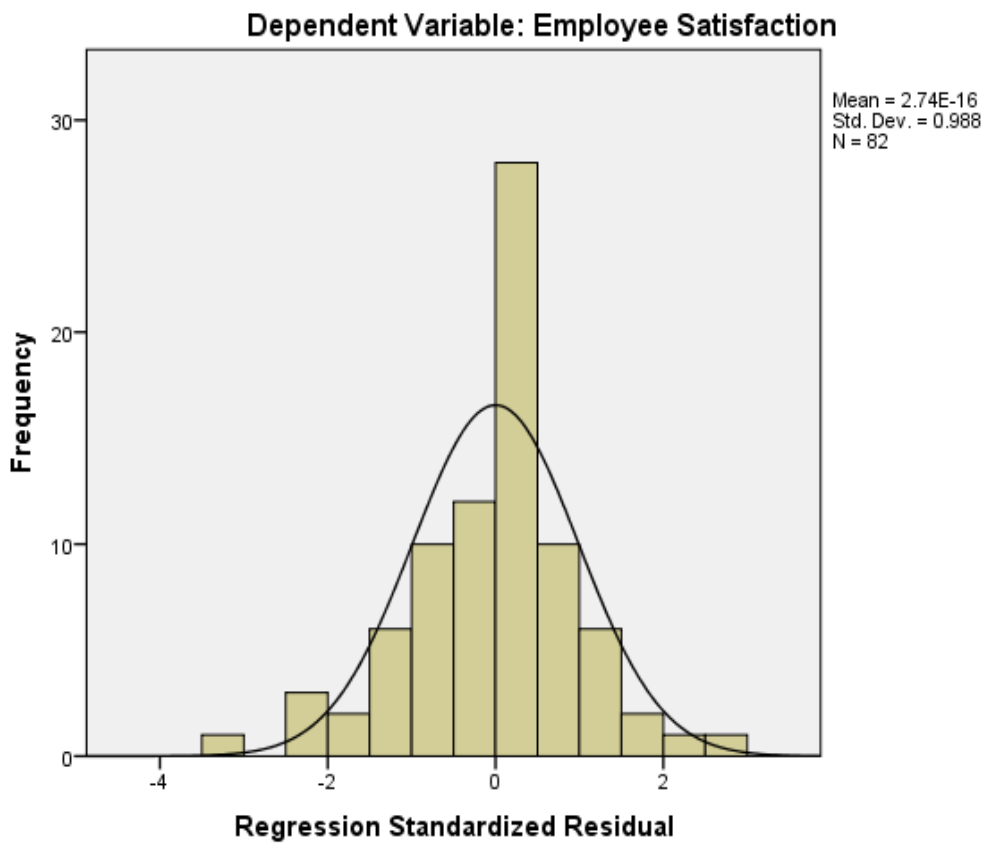


Based on the data above, it can be stated that the regression model in this study has normal data and meets the classical assumption test. Then for the next classic assumption test is multicollinearity test, are as follows:

Table 1. Multicollinearity Test

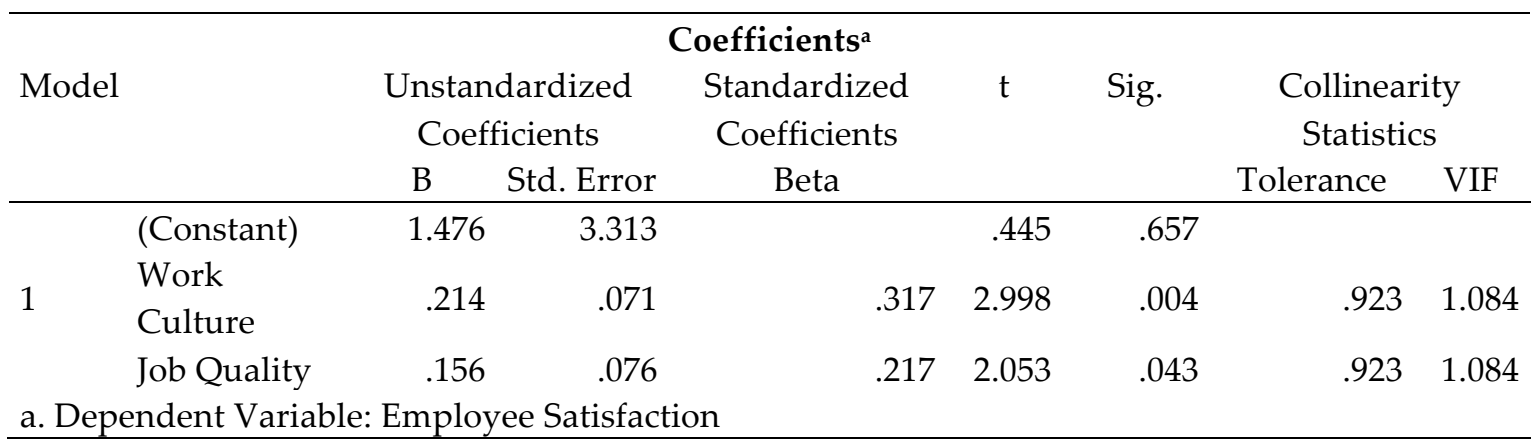

Based on the data above, it can be seen that for the tolerance value is large at 0.10 , while for the VIF value it is smaller than 10.00. This states that in the regression model multicolonierity symptoms do not occur. Next test is heteroscedasticity test, which can be seen below,

\section{Figure 3.}

\section{Heteroscedasticity test}

Scatterplot

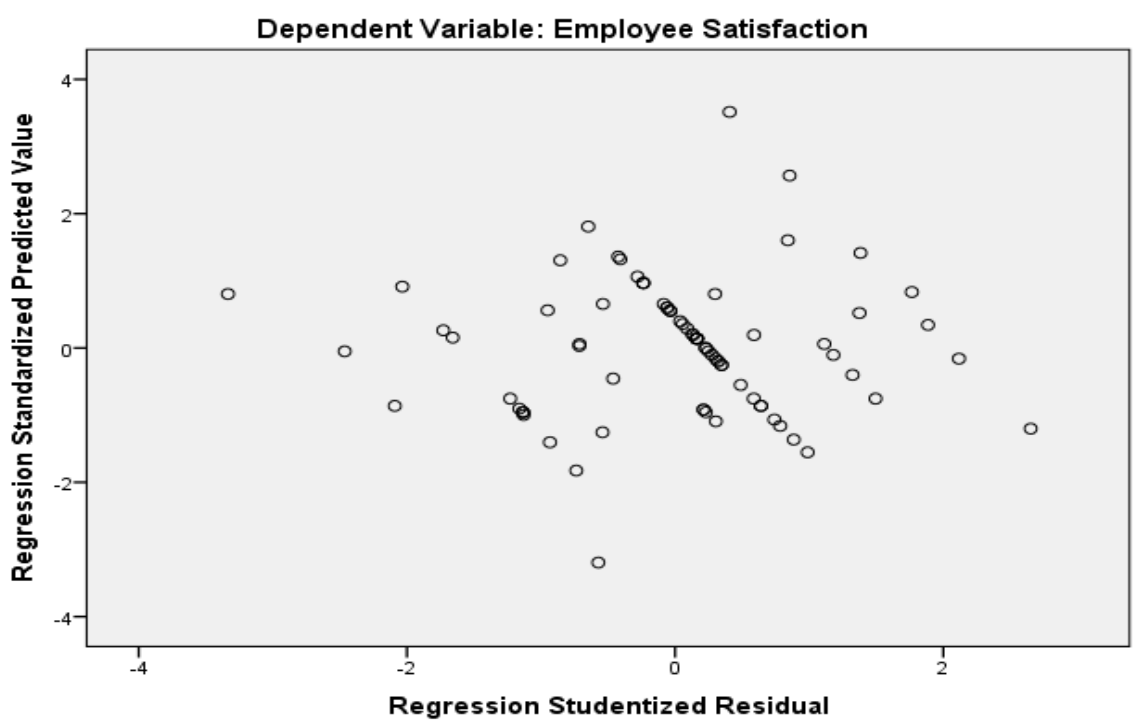

Based on the data above, it appears that the points are scattered above and below zero. Then the points are also patternless. It states that there is no heteroscedasticity problem, so that a good regression model can be met. Based on the classic assumption test that has been fulfilled, then the next test can be done. The steps to do a path analysis test using SPSS is to determine the regression of model I and model II. The first regression model is $\mathrm{X} 1$ to $\mathrm{X} 2$, which can be seen the results of the regression test as follows: 
Table 2.

Regression Test Model I (X1 against X2)

Model Summaryb

\begin{tabular}{lrrrr} 
Model & $\mathrm{R}$ & $\mathrm{R}$ Square & $\begin{array}{c}\text { Adjusted R } \\
\text { Square }\end{array}$ & \multicolumn{2}{c}{$\begin{array}{c}\text { Std. Error of } \\
\text { the Estimate }\end{array}$} \\
\hline 1 & $.278^{\mathrm{a}}$ & .077 & .066 & 3.267 \\
\multicolumn{3}{l}{ b. Dependent Variable: Job Quality } & & \\
\hline
\end{tabular}

\section{Coefficients $^{\mathrm{a}}$}

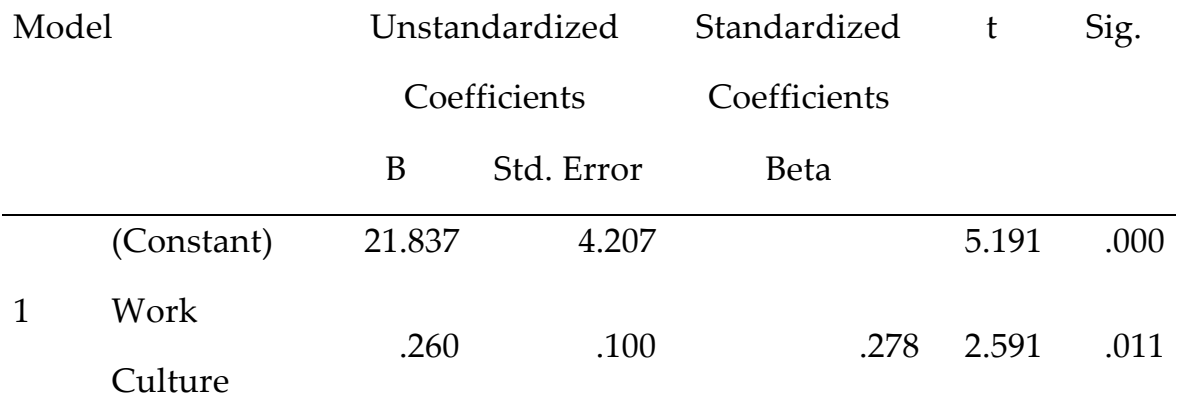

a. Dependent Variable: Job Quality

Table 3.

Model II Regression Test (X1, X2 against Y)

Model Summaryb

\begin{tabular}{lrrrr} 
Model & R & R Square & $\begin{array}{c}\text { Adjusted R } \\
\text { Square }\end{array}$ & \multicolumn{2}{c}{$\begin{array}{c}\text { Std. Error of the } \\
\text { Estimate }\end{array}$} \\
\hline 1 & $.431^{\text {a }}$ & .186 & .165 & 2.225
\end{tabular}

a. Predictors: (Constant), Job Quality, Work Culture

b. Dependent Variable: Employee Satisfaction

\begin{tabular}{|c|c|c|c|c|c|c|}
\hline \multicolumn{7}{|c|}{$\begin{array}{r}\text { Coefficients }^{a} \\
\end{array}$} \\
\hline \multirow[t]{2}{*}{ Model } & & Unstandardize & Coefficients & Standardized & $\mathrm{t}$ & Sig. \\
\hline & & B & Std. Error & Beta & & \\
\hline \multirow{3}{*}{1} & (Constant) & 1.476 & 3.313 & & .445 & .657 \\
\hline & Work Culture & .214 & .071 & .317 & 2.998 & .004 \\
\hline & Job Quality & .156 & .076 & .217 & 2.053 & .043 \\
\hline \multicolumn{7}{|c|}{ a. Dependent Variable: Employee Satisfaction } \\
\hline
\end{tabular}

Based on the regression output above, it can be seen in the first on the table coefficients model that the significance is smaller than 0.05 , which is 0.011 . This states that there is an influence of $\mathrm{X} 1$ toward $\mathrm{X} 2$ and the test results can be trusted $98.9 \%$. As for the 
amount of R Square contained in the Summary Model is 0.077. This shows that the influence of $\mathrm{X} 1$ toward $\mathrm{X} 2$ is $7.7 \%$.

In Model II, the coefficients table can be seen the significance of $\mathrm{X} 1$ toward $\mathrm{Y}$ is 0.004 and $\mathrm{X} 2$ toward $\mathrm{Y}$ is 0.043 . This states that the influence of $\mathrm{X} 1$ toward $\mathrm{Y}$ can be trusted 99.96\%, while the influence of X2 toward $\mathrm{Y}$ can be trusted $95.7 \%$. The amount of R Square contained in the Summary Model is 0.186 . This shows that the influence of $\mathrm{X} 1$ and $\mathrm{X} 2$ simultaneously toward $\mathrm{Y}$ is $18.6 \%$

The next step is to calculate the path coefficient. The path coefficient in this study is divided into two models, namely model I and model II. In model I, the beta value in the coeffecients table of variables $\mathrm{X} 1$ toward $\mathrm{X} 2$ is 0.278 . As for model II, the beta value in the coefficients table of variables $\mathrm{X} 1$ toward $\mathrm{Y}$ is 0.317 , and $\mathrm{X} 2$ toward $\mathrm{Y}$ is 0.217 .

The value of the path coefficient outside model I (e1) can be calculated by finding the root of 1 minus $R$ Square $(e 1=\sqrt{ } 1-R)$. The result is e $1 \sqrt{ } 1-0.077=0.923$. Whereas the value of the path coefficient outside model II (e2) is e $2=\sqrt{ } 1-0.186=0.814$. The model can be seen in the picture below,

\section{Picture 4.}

Path Analysis in This Research

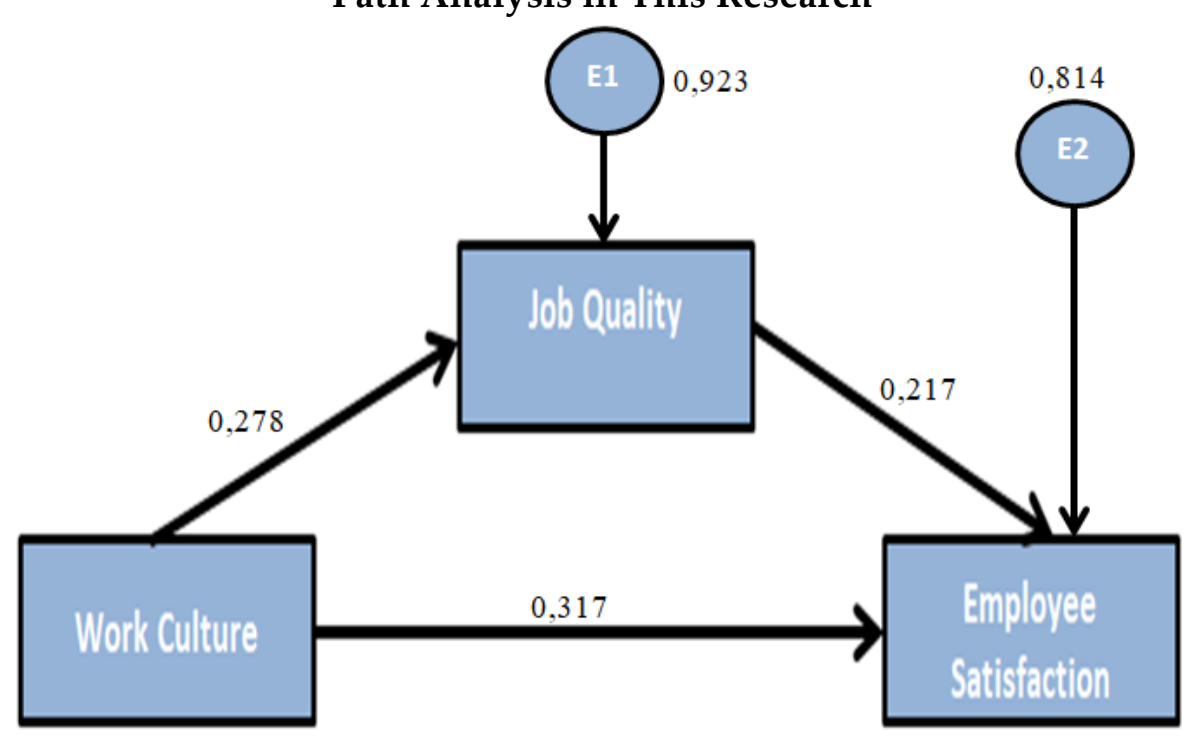

In the table above, the indirect effect of the variables $\mathrm{X} 1$ toward $\mathrm{Y}$ through $\mathrm{X} 2$ can be searched by multiplying the beta value $\mathrm{X} 1$ toward $\mathrm{X} 2$ with the beta value $\mathrm{X} 2$ toward $\mathrm{Y}$, which is $0.278 \times 0.217=0.0603$. Based on these results, it can be seen that the total effect of $\mathrm{X} 1$ toward $\mathrm{Y}$ is 0.3773 . The direct effect of $\mathrm{X} 1$ has a greater effect than the indirect effect on $\mathrm{Y}$. 
Based on the data above, this study found that work culture directly and indirectly has an influence towards employee satisfaction. Job quality can also be used as a variable connecting the work culture to employee satisfaction. The importance of work culture has a large influence on the organization. Work culture possessed by employees can bring organizational change to improve job quality and organizational quality (Schraeder, Jordan, \& Tears, 2005). The work culture can direct employees to be able to work quality and productive, which will be seen from the quality of work of these employees (Frinaldi, 2014). Quality work culture will help the organization to build a conceptualization that is compiled into a system of cognition as symbols, norms and shared meanings, so that the work culture contributes to the quality of employee work in the organization.

work culture is related to quality of work. If there are some employees who have a low commitment work culture, it means that there is a disruption to the quality of work and work performance to be achieved. Therefore, socialization and internalization of work culture for employees should be the main program (Kurniawan, Lubis, \& Adam, 2012). In organizations, the quality of work has a strategic importance that influences organizational performance. Job quality also has a positive impact on organizational commitment and performance. In addition, high job quality decreases employee turnover intentions(Appelbaum, Bailey, Berg, \& Kalleberg, 2000; Green, 2006). Therefore, it is necessary for an organization to be able to provide a good culture at work, so that highquality employees at work can be maintained (Ruuskanen, Selander, \& Anttila, 2016).

Based on the data above, work quality has become an intervening variable, which has not contributed greatly to the work culture to influence employee satisfaction. This is because there are still other factors that affect work quality, such as work experience, level of education, work contracts, hours of work, formal status of the company and affiliation to the union (Kponou \& Kamga, 2019).

Employee satisfaction is defined as a comparison between expectations and reality at work. If what is obtained is far from expectations, the employee is not satisfied and if in accordance with expectations, the employee is satisfied. But the process is more complicated than what appears. It is more important for any organization to offer high satisfaction, because it reflects high loyalty and it will not cause a transition once a better offer is entered (Mishra, 2013). 


\section{Conclusion}

Based on the results of this study, it was found that directly and indirectly, there was an influence of work culture on job satisfaction. Indirectly, joq quality can be a link between work quality and job satisfaction. However, based on this study, the direct effect has a greater effect than the indirect effect through joq quality. Therefore, further research is needed to be able to see other variables that affect the relationship between work culture variables and job satisfaction.

\section{References}

Appelbaum, E., Bailey, T., Berg, P., \& Kalleberg, A. L. (2000). Manufacturing Advantage: Why High-Performance Work Systems Pay Off. Ithaca: Cornell University Press.

Cheng, Z., Nielsen, I., \& Cutler, H. (2017). Perceived job quality, work-life interference and intention to stay Evidence from the aged care workforce in Australia. International Journal of Manpower. https://doi.org/10.1108/IJM-08-2017-0208

Clark, A. E. (2005). Your money or your life: Changing job quality in OECD countries.

Edvardsson, B., \& Enquist, B. (2002). The IKEA saga: How service culture drives service strategy. The Service Industries Journal, 22(4), 153-186.

Frinaldi, A. (2014). Pengaruh Budaya Kerja Pegawai Negeri Sipil Terhadap Pelayanan Publik di Dinas Catatan Sipil dan Kependudukan Kota Payakumbuh. Humanus, 13(2), 180-192. https://doi.org/10.24036/jh.v13i2.4727

Frinaldi, A. (2017). The Influence of Driver Work Culture and Service Quality on Citizen Satisfaction with Mass Transportation. Atlantis Press, 84, 450-453. Retrieved from http://creativecommons.org/licenses/by-nc/4.0/

Frinaldi, A., \& Embi, M. A. (2013). Budaya Kerja 'Giot Ipas' dalam Kalangan Pegawai Negeri Sipil Etnik Mandailing (Studi Kasus pada Kabupaten Pasaman Barat, Provinsi Sumatera Barat). Jurnal Ilmiah Ilmu-Ilmu Humaniora.

Frinaldi, A., Khaidir, A., \& Rahayu. (2019). Policy Management to Develpo Tourism Work Culture Consciousness and Increasing Visiting People's Satisfaction. Jurnal Studi Pemerintahan, 10(1), 49-67. https://doi.org/10.18196/jgp.10197

Green, F. (2006). Demanding Work: The Paradox of Job Quality in the Affluent Economy. Princeton: Princeton University Press. 
Kponou, K., \& Kamga, B. F. (2019). Job quality dynamic in Benin. The International Journal, 41(3), 475-488. https://doi.org/10.1108/ER-02-2018-0059

Kurniawan, D., Lubis, A. R., \& Adam, M. (2012). Pengaruh Budaya Kerja Dan Motivasi Kerja Terhadap Kinerja Karyawan International Federation Red Cross (Ifrc) Banda Aceh. Jurnal Ilmu Manajemen., 1(1), 1-16.

Parasuraman, A., Zeithalm, V. A., \& Berry, L. L. (1988). SERVQUAL, A multiple-item scale for measuring consumer perceptions of servic e quality. Journal of Retailing, 12-40.

Ruuskanen, P., Selander, K., \& Anttila, T. (2016). Third-sector job quality: Evidence from Finland. Employee Relations, 38(4), 521-535. https://doi.org/10.1108/ER-06-2015-0134

Schraeder, M., Jordan, M. H., \& Tears, R. S. (2005). Organizational culture in public sector organizations: Promoting change through training and leading by example. Leadership \& Organization Development Journal, 26(6), 492-502. https://doi.org/10.1108/01437730510617681

Sisson, P., Green, A., \& Lee, N. (2017). Improving Job Quality in Growth Sectors: A Review of the International Evidence. Public Policy Institute for Wales.

Takada, P. W., \& Westbrook, J. W. (2009). The Impact Of Organization Culture On Satisfaction Of Engineers In Technology. University Of Alabama In Huntsville.

Tjiptono, F., \& Chandra, G. (2007). Service, Quality \& Satisfaction Edisi 2. Yogyakarta: Penerbit Andi. 